F. Reprod. Fert. (1975) 45, 505-508

\title{
NATURE OF THE STIMULUS OF THE COPULATION-INDUCED RISE IN LACTIC DEHYDROGENASE ACTIVITY IN THE RABBIT OVIDUCT
}

\author{
S. K. VARMA AND G. P. TALWAR \\ Department of Biochemistry, All-India Institute of Medical Sciences, \\ New Delhi-110 016, India
}

(Received 26th February 1975)

It has been reported that there is an increase in the activity of acid phosphatase, alkaline phosphatase and lactic dehydrogenase in different regions of the rabbit oviduct within $14 \mathrm{hr}$ after mating (Varma \& Talwar, 1973; Varma et al., 1974). Concomitant with the increase in the total activity of the lactic dehydrogenase $\left(\mathrm{LDH} ; \mathrm{L}(+)\right.$-lactate: $\mathrm{NAD}^{+}$oxidoreductase, EC 1.1.1.27), there is a shift in the isoenzymic pattern of the enzyme, and the M-form of the enzyme (which favours the formation of lactate) increases markedly in the organ (Varma et al., 1974). The stimulus for these changes is not yet known, but is presumably hormonal or neural. The present investigations were undertaken to examine the factor(s) responsible for these metabolic changes.

Sexually mature female rabbits, bred in the Institute colony and weighing $2-2.5 \mathrm{~kg}$, were used. The rabbits were caged separately for at least 3 weeks before use and were allowed free access to food and water. Ovulation was induced by mating with a fertile buck, and confirmed at autopsy by the presence of ovulation points.

The animals were killed by injecting air into the ear vein or with a lethal dose of sodium pentobarbital (Nembutal: Abbott Laboratories, Chicago, Illinois). The oviducts were rapidly removed, trimmed of supporting mesentery on an ice-cold glass plate and flushed with $0 \cdot 15 \mathrm{~m}-\mathrm{NaCl}$ to remove spermatozoa. The infundibulum, ampulla and isthmus were separated by the procedure described by Greenwald (1961). The tissues were blotted, weighed to the nearest $0.1 \mathrm{mg}$, minced and homogenized in $3.0 \mathrm{ml}$ of $100 \mathrm{~mm}$-sodium phosphate buffer $(\mathrm{pH}$ 7.5). The $105,000 \mathrm{~g}$ supernatants were used as the enzyme source for the LDH assay. The activity of LDH was determined as described by Varma et al. (1974). A total volume of $1 \mathrm{ml}$ assay medium contained $50 \mathrm{~mm}$-phosphate buffer, 0.15 mm-NADH and 2 mm-pyruvate. For the $\mathrm{H}$ - and $\mathrm{M}$-types of the enzyme, the assays were performed in the presence of $2 \mathrm{~mm}$ - ( $\mathrm{H}$ and $\mathrm{M}$ activity) and $30 \mathrm{~mm}$ (M activity) pyruvate concentrations.

Protein concentrations were determined by the method of Lowry et al. (1951) with crystalline bovine serum albumin as the standard.

The hormones used were: LH (NIH-LH-S18) at $20 \mu \mathrm{g} / \mathrm{kg}$ body wt; prolactin (NIH-P-S10) at $20 \mu \mathrm{g} / \mathrm{kg}$ body wt; 20 -hydroxypregnen-3-one (Ikpharm, 
Israel) at $3 \mathrm{mg} / \mathrm{kg}$ body wt; progesterone (Sigma, St Louis) at $3 \mathrm{mg} / \mathrm{kg}$ body wt; and oestradiol-17 $\beta$ (Sigma, St Louis) at $10 \mu \mathrm{g} / \mathrm{kg}$ body wt.

In order to evaluate the effects of adrenergic stimulation and blockade, the adrenergic drugs were injected into the ear vein in sterile $0.9 \% \mathrm{NaCl}$. The drugs used were: norepinephrine (L-arterenol hydrochloride: Winthrop, New York) at $4 \mu \mathrm{g} / \mathrm{kg}$ body wt; isoproterenol (Isuprel: Winthrop) at $5 \mu \mathrm{g} / \mathrm{kg}$ body wt; phenoxybenzamine (dibenzyline: Smith, Kline and French Laboratories, Philadelphia, Pennsylvania) at $3 \mathrm{mg} / \mathrm{kg}$ body wt; and propranolol (Indreral: Ayerst Laboratories Inc., New York) at $5 \mathrm{mg} / \mathrm{kg}$ body wt. The animals were mated 10 min after the administration of phenoxybenzamine or propranolol. The animals were killed $14 \mathrm{hr}$ after mating or hormone or drug administration.

In the first set of experiments, the effects of those hormones whose levels were likely to increase (Desjardins et al., 1967; Keyes \& Nalbandov, 1968) as a result of mating and ovulation were investigated. The results in Table 1 show that $\mathrm{LH}$ induced a rise in the activity of $\mathrm{LDH}$, indicated by the change in tissue weight and protein content, to an extent equivalent to that induced by mating. The LH therefore appeared to specifically affect the activity of $\mathrm{LDH}$, and the rise in the enzyme activity was not a reflection of a generalized effect of the hormone on protein synthesis in the tissue.

Table 1. Lactic dehydrogenase activity in different regions of the rabbit oviduct $14 \mathrm{hr}$ after mating or after administration of $\mathrm{LH}$

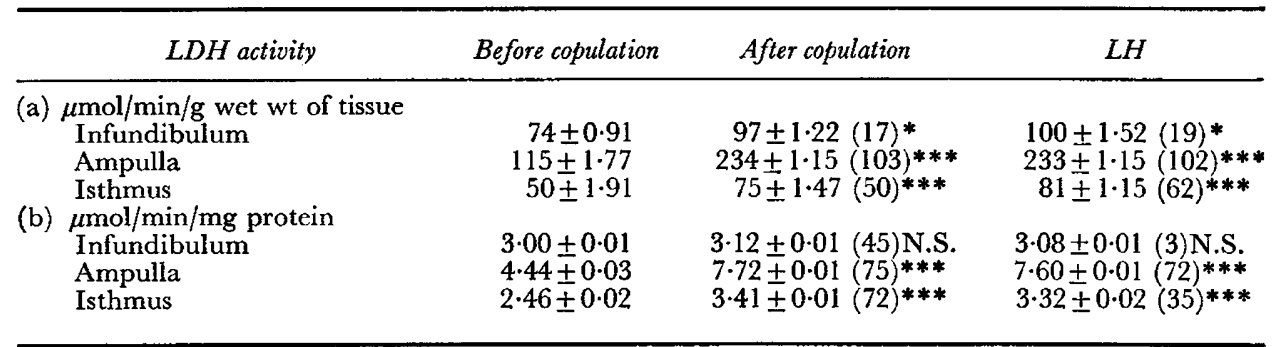

Values are Means \pm S.E.M. for four experiments. Figures in parentheses are the $\%$ increase over the precopulatory levels of $\mathrm{LDH}$ in that region of the oviduct.

$* P<0.002 ; * * * P<0.001 ;$ N.S., not significant.

Prolactin, 20 $\alpha$-hydroxypregnen-3-one and progesterone also affected the activity of $\mathrm{LDH}$, but the rise was less than that found after ovulation (Text-fig. 1a). There was no change after oestrogen treatment.

Varma et al. (1974) noticed that copulation increased not only the total LDH activity in discrete regions of the oviduct, but also that there was a shift in the proportion of the isoenzymes; the percentage of M-type increasing and that of $\mathrm{H}$-type decreasing. The effects of hormones, particularly $\mathrm{LH}$, on the isoenzyme profile was therefore investigated to see whether these hormones simulate fully the changes occurring in the tissue after copulation. It was found that LH and to some extent the other hormones caused an increase which varied from 16 to $40 \%$ of the M-type isoenzyme, but that the H-type was decreased by $16-27 \%$ after LH treatment. 


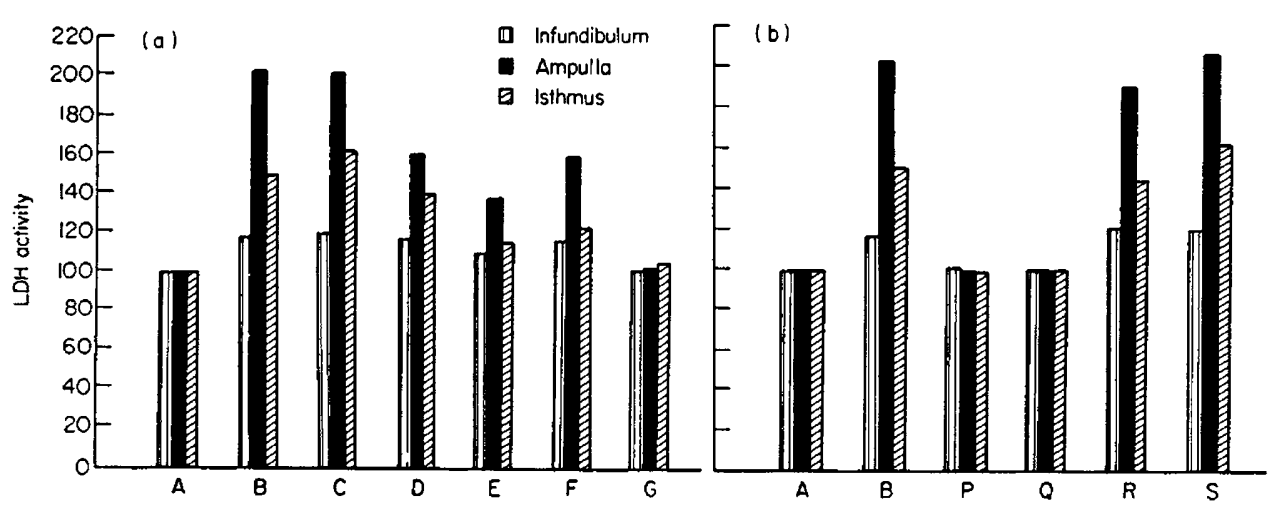

TEXT-FIG. 1. The effects of various substances on the LDH activity in three regions of the rabbit oviduct. The activity in a control oestrous rabbit (A), $84 \mu \mathrm{mol}$ pyruvate converted to lactate $/ \mathrm{min} / \mathrm{g}$ wet weight of tissue, is taken as $100 \%$. All values are the means of four experiments. In (a) the S.E.M. was within $\pm 1.52, \pm 2.04$ and \pm 1.91 for the infundibulum, ampulla and isthmus respectively. B, $14 \overline{\mathrm{hr}}$ after copulation; C, $40 \mu \mathrm{g} \mathrm{LH} ; \mathrm{D}, 45 \mu \mathrm{g}$ prolactin; E, $6 \mathrm{mg} 20 \alpha$-hydroxypregnen-3-one; F, $7 \mathrm{mg}$ progesterone; G, $22 \mu \mathrm{g}$ oestradiol-17 $\beta ; \mathrm{P}, 10 \mu \mathrm{g}$ norepinephrine; $\mathrm{Q}, 12 \mu \mathrm{g}$ isoproternol; $\mathrm{R}$, copulation $+7 \mathrm{mg}$ phenoxybenzamine; $\mathrm{S}$, copulation $+10 \mathrm{mg}$ propanolol.

Since norepinephrine is reported to be the main adrenergic neurotransmitter in the oviduct (Brundin, 1969; Sjöberg, 1972), the influence of norepinephrine on the activity of LDH was investigated. No increase in LDH activity was found (Text-fig. 1b). Isoproterenol, a stimulator of $\beta$-adrenergic receptors, was also without effect. Exogenous administration of these substances may not necessarily result in appropriate concentrations at the site of action in the tissue. Experiments were performed therefore to determine whether the inhibitors of $\alpha$ and $\beta$-adrenergic receptors, such as phenoxybenzamine and propranolol, can block the copulation-induced rise in LDH activity in various regions of the oviduct. The results in Text-fig. 1(b) show that mating caused the usual rise in LDH activity in spite of the presence of these inhibitors.

These results suggest that the stimulus for the change in the metabolic activity of the rabbit oviduct after copulation is hormonal. Most probably $\mathrm{LH}$ is the hormone responsible for this change, although prolactin and progesterone were also partly effective. The involvement of these hormones is further corroborated by the similarity of the isoenzymic pattern of LDH in oviducts removed $14 \mathrm{hr}$ after mating or $14 \mathrm{hr}$ after administration of the hormones.

This work was supported by research grants from the Indian Council of Medical Research, the PL-480 grant No. NR 202-028 of the Office of Naval Research and the World Health Organization, Geneva (Human Reproduction Division).

\section{REFERENCES}

Brundin, J. (1969) Pharmacology of the oviduct. In The Mammalian Oviduct, pp. 251-269. Eds E.S.E. Hafez \& R.J. Blandau. University of Chicago Press, Chicago.

Desjardins, C., Kirton, K.T. \& Hafs, H.D. (1967) Anterior pituitary levels of FSH, LH, ACTH and prolactin after mating in female rabbits. Proc. Soc. exp. Biol. Med. 126, 23-26. 
Greenwald, G.S. (1961) A study of the transport of ova through the rabbit oviduct. Fert. Steril. 12, $80-95$.

KeYes, P.L. \& Nalbandov, A.V. (1968) Endocrine function of the ovarian interstitial gland of rabbits. Endocrinology 82, 799-804.

Lowry, O.H., Rosebrough, N.J., FarR, A.K. \& Randall, R. J. (1951) Protein measurement with the Folin phenol reagent. f. biol. Chem. 193, 265-275.

SJÖBERG, N..O. (1972) Hormonal control of adrenergic innervation in tubal smooth musculature. Excerpta Med. Int. Congr. Series, No. 256, p. 264, Abstr.

VARMA, S. K. \& TAlWAR, G. P. (1973) Changes in the activity of two enzymes in rabbit fallopian tube following copulation and hormonally induced ovulation. Ind. F. med. Res. 61, 1841-1845.

Varma, S. K., Srivastava, L. M. \& Talwar, G. P. (1974) Changes in the activity and isozymic forms of lactic dehydrogenase in the rabbit oviduct following copulation. F. Reprod. Fert. 39, 131-134. 